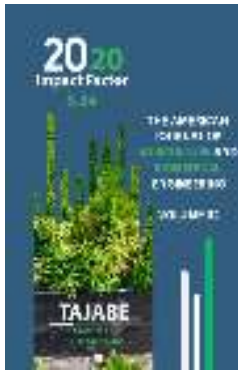

Journal Website: http://usajournalshub.c om/index,php/tajabe

Copyright: Original content from this work may be used under the terms of the creative commons attributes 4.0 licence.

\section{Biology Of Sugar Beet, As Well As The Scientific Basis For The Cultivation Of Ecologically Pure Products}

\author{
Mirzayeva Mutabar Azamovna \\ Candidate Of Agricultural Sciences, Associate Professor Of The Department "Technology Of \\ Storage And Primary Processing Of Agricultural Products", Fergana Polytechnic Institute, \\ Fergana, Uzbekistan
}

Akramov Shohruh Shuhratjon O'g'li

Assistant, Department "Technology Of Storage And Primary Processing Of Agricultural Products", Fergana Polytechnic Institute, Fergana, Uzbekistan

\author{
Abdukarimova Dinara Nuritdinovna \\ Assistant, Department “Technology Of Storage And Primary Processing Of Agricultural \\ Products", Fergana Polytechnic Institute, Fergana, Uzbekistan \\ Ne'matova Feruza Jamol Qizi \\ Assistant, Department “Technology Of Storage And Primary Processing Of Agricultural \\ Products”, Fergana Polytechnic Institute, Fergana, Uzbekistan
}

\title{
ABSTRACT
}

This article describes the biology of sugar beet, cultivation technology, diseases and pests, as well as effective methods of combating them. The scientific work on the cultivation of sugar beet was studied and appropriate recommendations were given.

\section{KEYWORDS}

Yield, disease, pest, water shortage, soil, temperature, humidity, drought, tubers.

\section{INTRODUCTION}

Consistent economic reforms in agriculture will fully meet the demand of the population for quality food products and at the same time, the prevention of food insecurity, which is one of the biggest challenges today, is one of the most actual issues. Growing tubers occur in the spring and summer months. Therefore, it is impossible to fully provide the population with agricultural products without the proper organization of harvesting and primary processing of these products, as far as possible, without destruction. As the volume of root crops grows, their storage and processing are improving, and new modern warehouses and processing enterprises are being built [1-3].

Sugar beet is the most important technical crop grown for sugar production. Its tubers 
The American Journal of Agriculture and Boimedical Engineering (ISSN - 2689-1018)

Published: November 21, 2020 | Pages: 7-10

Doi: https://doi.org/10.37547/tajabe/Volume02Issue11-02

contain $16-22 \%$ sugar. When the yield of root fruit is $40-50 \% \mathrm{t} / \mathrm{ha}$, it can accumulate $7-8$ tons of sugar per 1 hectare. In sugar factories, molasses and lees remain after sugar is produced. The dry matter of molasses contains $60 \%$ sugar, $15 \%$ nitrogen-free substances, and 8 $9 \%$ ash. Alcohol and glycerin are extracted from molasses. The lees contain 15\% dry matter, 10\% nitrogen-free matter, $0.1 \%$ fat and $1.25 \%$ protein. Lees is a high-quality feed for livestock: $100 \mathrm{~kg}$ of dry lees contains 80 feed units. When 30 tons of sugar beet are harvested from one hectare, 24 tons of lees is produced. Sugar production waste - defecation waste is used as fertilizer. It contains $40-50 \%$ lime, organic matter 15\%, $\mathrm{H}-0.2-1.7, \mathrm{R}_{2} \mathrm{O} 5-0.2-08$ and $\mathrm{K}_{2} \mathrm{O}$ $0.5-0.9 \%[4-6]$.

In Uzbekistan, sugar is mainly obtained from sugar beets. Sugar beet has been grown in our country mainly since 1942. Since 1993, under the leadership of Dr. R. Tillaev, research work has been carried out at the SUVAIET of Cotton Breeding and Seed Production. The research was conducted by B.Khalikov in Tashkent region, by I.Sulaymonov in Andijan region, by R.Kurbanov in Fergana region. Later, in 19972006, scientific research was conducted to test varieties of sugar beet in Khorezm, Kashadarya and Tashkent regions. According to the botanical description of beets, a biennial plant with tubers is belonging to the genus Beta vulgares. Experiments have shown that the yield can be 337-401ts / ha. B.Khalikov (2001) Sugar beet is a biennial plant, which in the first year of life forms a collection of thickened roots and leaves. The duration of this period is 150-170 days. In the second year of life, the roots are located in the leaf axils. From dormant buds leaves, flowers are formed $[7,8]$. The seeds ripen 100-125 days after planting the tubers. In the year the seeds are sown, flowering stems are formed, while flowering plants are formed. Flowering is observed when planted early when the spring is cool when the relatively light day is long when the flowering period is short. During flowering, the amount

of sugar in the roots decreases, the roots thicken and shrink. In the first days of plant life, the primary roots develop slowly. In the first year of vegetation, three main periods can be distinguished. 1. Formation of the absorbing surface of leaves and root. 2. Strong growth of leaves and roots lasts for two months. 3. Rapid accumulation of sugar, roots increase by $5 \mathrm{~g}$ per day, an increase in sugar 0, 07-0.1\% was found in experiments.

\section{MATERIALS AND METHODS}

Sugar production around the world has varied over the years, depending on the yield of sugar cane and sugar beet. At present, an average of 80-100 million tons of sugar is produced annually. The world produces $60-65 \%$ of sugar cane and $35-40 \%$ of sugar beet.

Sugar plays an important role in a person's diet. Beet-sugar products in the Central Economic Food Complex play an important role, and sugar beet processing is also beneficial for the agricultural production complex, the demand for these products is growing. Therefore, in the economy, unfortunately, it is necessary to focus on the development and improvement of this sector, which is gradually declining. Therefore, the development of recommendations to increase the economic efficiency of sugar beet cultivation is of great practical importance.

Achieving the goal requires the development and thorough study of the following tasks:

1.

2.

3.
A detailed study of the general economic characteristics of the economy, including crop and livestock production;

Analysis of the financial stability of the agricultural production complex;

To consider the economic efficiency of all activities of the economy; 
4. To determine the role and place of sugar beet in the production activities of the economy;

5. Organization of sugar beet production and analysis of its economic efficiency;

6. Analysis of the relationship between the agricultural production complex and the sugar beet processing plant;

7. Propose basic measures to improve the organization of production and sale of sugar beet and its processed products.

There are two main sugar factories in the country, which are located in the Khorezm region and Angren. And therefore, mainly sugar beet in our region, Khorezm region, it is grown only in some areas of Tashkent region and partially in Samarkand and Karakalpakstan. Therefore, studying the biology of sugar beet, agrotechnology of cultivation shows that in other regions of the country we can get a higher yield by setting the agrotechnology of cultivation of sugar beet. This will increase the area under sugar beet. Then we will be able to build a sugar factory in other parts of the region, including the Central Fergana region. In this regard, it is advisable to unite sugar beet farms in the agro-industrial complex, as it may be a little difficult for farms to accomplish this task alone. At the same time, it is very difficult to replenish the working capital of farms needed to grow the required amount of sugar beet for the plant[6-9].

It needs a management investment company to help it. High productivity of sugar beet and the level of sugar content is one of the main factors influencing the reduction of its cost and increase the profitability of its production, which in turn is associated with the preservation of sugar in sugar beet processing at the plant. To do this, the sugar factory and the management company need to create a

machine-technological station with the appropriate beet equipment on the shares.

But in addition to reforming the sugar beet industry through cooperation and agricultural integration, producers, sugar mills and investment companies need to achieve a modern competitive production level based on the application of the world's best achievements.

\section{CONCLUSION}

In conclusion, by studying the biology, agrotechnical and cultivation technology of sugar beet, it is expedient to plant and process sugar beet in the desert and semi-desert areas of Central Fergana on lands with different levels of salinity, unsuitable for the main crop cotton. Such lands cover 20,000 hectares in the region. Also, livestock can be developed in the region through the waste generated during storage and processing of the crop. Most importantly, we would be able to provide the population of our region with relatively cheaper sugar products through the processing of sugar beet.

\section{REFERENCES}

1.

2.

3.
Sh.T.Khojaev. (2010). Entomology, protection of agricultural crops and basics of agrotoxicology, -Tashkent: Science. pp. 120-121.

Xoliqov.B.M.

(2013).

Agrotechnology of sugar beet cultivation and crop rotation. Toshkent; Navruz Publishing House. pp. 94-95.

H.Ch.Buriev, R.Juraev, O.Alimov. (2002). Storage and primary processing of agricultural products. Tashkent, "Labor". 
4. 4. Abdurakhmonov, S. Zh., Akramov, Sh. Sh., \& Bakhtiyorova, D. F. (2018). Regulation of the fruiting of cotton by removing some of the newly formed buds. Actual science, (11), 18-21.

5. Ibragimov, O. O., \& Akramov, Sh. Sh. (2018). Regulirovanie plodonosheniem khlopchatnika putem udaleniya chasti novoobrazuyushchikhsya butonov. Sovremennye nauchnye issledovaniya i razrabotki, (6), 314315.

6. Nazirova, R. M., Tadjiev, S. M., Mirsalimova, S. R., \& Akramov, Sh. Sh. (2018). Intensivnaya tekhnologiya polucheniya PKudobrenii. Sovremennye nauchnye issledovaniya i razrabotki, (3), 415418.

7. Shohruh, A. (2020). The biology of sugar beet, the scientific bases of disease and pests, also rearing ecological health nutrition. Electronic journal of biology and ecology, 2(1).

8. Nazirova, R., Usmonov, N., \& Askarov, K. (2020). Technology of storing grain in a cooled state. Збірник наукових праць $\Lambda$ 'ОГО 93-95.

9. Nazirova, R. M., Usmonov, N. B., \& Bakhtiyorova, D. (2020). Innovative technologies for grain storage of different crops. ACADEMICIA: An International Multidisciplinary Research Journal, 10(6), 222-228. 